\title{
Ecotoxicological state and pollution status of alluvial soils of St. Petersburg, Russian Federation
}

\author{
Vyacheslav Polyakov $^{1 *}$, Oleg Reznichenko ${ }^{1}$, Jakub Kostecki ${ }^{2}$, Evgeny Abakumov ${ }^{1}$ \\ ${ }^{1}$ Department of Applied Ecology, Faculty of Biology, Saint-Petersburg State University, 16th Liniya 29, Vasilyevskiy Island, Saint-Petersburg, \\ 199178, Russian Federation \\ ${ }^{2}$ University of Zielona Góra, Institute of Environmental Engineering, 15 Prof. Z. Szafrana St., 65-516 Zielona Góra, Poland \\ * V. Polyakov, slavon6985@gmail.com, ORCID iD: https://orcid.org/0000-0001-6171-3221
}

Received: 03.06.2020

Accepted: 01.09.2020

Associated editor: J. Antonkiewicz

\section{Keywords}

Soil contamination Urban soil, Technosols Artificial territory Podzols

\begin{abstract}
According to the main chemical indicators, the soils of the city differ significantly from their natural analogue. A significant part of the territory of cities is affected by negative processes that affect the ecological functions of soils. Due to the intensification of the anthropogenic impact, surface air pollution increases, soil profiles are disturbed, acidity and alkalinity change, and the biodiversity of soil microflora is reduced. This paper presents the results of a study of alluvial urban soils of parks and the industrial zone located in Saint Petersburg in Russia. A morphological description and the basic physical parameters of soils are determined. The content of priority toxicants (heavy metals, benzo[a]pyrene, petroleum products) was conducted, as well as an epidemiological study of soils for the presence of pathogenic organisms. The data obtained show that heavy metals accumulate in alluvial soils, about $35 \%$ of the studied soils exceeded permissible concentrations. The content of PAHs in soils also exceeded up to 34 of the maximum permissible concentration. We observe differences in the sanitary and hygienic conditions of alluvial territories specially designated for recreational area. According to the results of microbiological studies, pathogenic organisms are present in soils, but their content varies within acceptable limits of Russian Federation.
\end{abstract}

\section{Introduction}

Within the urban ecosystem, soils are distinguished by composition and properties (Short et al., 1986). Natural landscapes are transformed into anthropogenic with a local change in biochemical cycles (accumulation and removal of chemical elements (Adama et al., 2016; Dymov et al., 2013). Urban soils, as a depositing component of the urban landscape, accumulate many trace elements, including heavy metals and metalloids, as well as organic compounds that are toxic to living organisms (Kicińska, 2019). The most common heavy metals (HM) are Cu, $\mathrm{Zn}, \mathrm{Ni}, \mathrm{Co}, \mathrm{Fe}, \mathrm{Mn}, \mathrm{Pb}, \mathrm{Cr}, \mathrm{Cd}$ (Ji et al., 2019). Many of them are biophilic and necessary for the normal functioning of living organisms, but with a significant increase in their content in the soil become toxic (Kicińska et al., 2019). Regardless of the soil type, technogenic territories are characterized by a regressiveaccumulative type of distribution of heavy metals along the soil profile: metals accumulate in the upper humus horizon of the soil and a sharp decrease in their concentration to the bottom of profile (Bi et al., 2006).
According to the main chemical indicators, the soils of the city differ significantly from their natural analogue (Blume, 1989; Wei and Yang, 2010). The acidity of the root layer of urban soils varies widely, but soils with a neutral and slightly alkaline environment prevail. The reaction of the urban soil environment is higher than that of natural soils (Huot et al., 2013). The exchange cations are dominated by $\mathrm{Ca}$ and $\mathrm{Mg}$. Plant nutrients $(\mathrm{N}, \mathrm{P}, \mathrm{K})$ in urban soils are distributed unevenly. High enrichment of bulk layers and slightly disturbed soils with general nitrogen, phosphorus and potassium is noted, compared with the natural soils of the suburbs. In them, enrichment with mobile forms of elements is also noted (Ge, 1992; Iyengar and Nair, 2000).

The lack of free territories is very noticeable in the coastal areas of the settlements. This problem is especially relevant for St. Petersburg, where population density is constantly increasing, infrastructure is developing, and the area of industrial territories is growing (Abakumov et al., 2019). For a long period, St. Petersburg was cut off from the Gulf of Finland by flooded area, which were often flooded for 1-2 km from the coastline. The boundaries of the city for a long time did not expand due to the 
flood areas of land surrounding the city, characterized by a high peat content of soils. From the 60s of the XX century, engineering and planning work began on leveling the coastline, swampy shores of the Gulf of Finland in order to form a marine facade in St. Petersburg (Kapelkina, 2010a).

Alluvial soils of St. Petersburg were studied by Kapelkina (1994, 2010b). Her works deal with succession vegetation, agrochemical and physical properties of soil, in particular in the territory of South Seaside Park. Soil forming processes on alluvial soils, morphological features of the soil cover are described in detail in the work of Maksimova and Abakumov (2015), also briefly describes the stages of transformation of the coastal zone of St. Petersburg, the experience of Russian and foreign countries. Characteristics of the physicochemical properties of soils in the alluvial territories of St. Petersburg are provide by Chasovskaya (2007).

For the reclamation of territories, slightly silted fine-grained dusty sands and sandy loams are used, lining the bottom in shallow parts of the bay. Well-drained fine-grained sands serve as the underlying ground for the alluvial soils, while buried peat bogs occur on the bottom of the gulf, the presence of which was due to the transgression and regression of the Baltic Sea. The alluvial soils contain silty organic particles, plant and animal sediments, as well as organic matter from plankton and benthos. They contain vegetative parts of plants (stems, rhizomes), as well as seeds and dust grains. Clay material and organic particles impart significant hydrophilicity to alluvial soils, causing slow water loss (Bogdanov, 2014; Kapelkina, 2010b).

In alluvial soils fractions of fine sand and coarse dust prevail and having a low absorption capacity. The high content of dusty particles in the composition of the soil gives them low water permeability and the presence of a small amount of clay and silty particles increases the water-holding and absorption capacity, slowing down water loss. Water properties of alluvial soils (moisture capacity, filtration, capillary elevation height) are largely determined by the mutual arrangement and granulometric composition of the layers. The heterogeneity and stratification of soils contribute to an increase in the total field water capacity of the profile (Li et al., 2014). Due to the stratified structure of soils, some of which are finely dispersed fractions forming water-resistant horizons and lead to bogging processes in landscape. In general, alluvial soils within the alluvial area are characterized by great heterogeneity and different moisture capacity (Kapelkina, 2010b; Cappuyns and Swennen, 2007).

The soils of St. Petersburg city parks are formed under the influence of strong anthropogenic impact. The soils of the recreational territories (the 300th anniversary park of St. Petersburg and the South Seaside Park) differ in the degree of urbanization, which determines their disturbance under anthropogenic impact, as well as in agrochemical properties: clay content, acidity, degree of base saturation, phosphorus and potassium content. Soils have a relatively high fertility in terms of humus content (Kapelkina, 2010b).

Soil compaction is typical for anthropogenic soils, especially park areas due to their high attendance, low porosity, the introduction of pollutants of anthropogenic origin, including through the aquatic environment due to the processes of period- ic flooding in alluvial territories, invariably cause the formation of specific characteristics of the studied soils on the territory of St. Petersburg. According to our hypothesis, the artificial alluvial territories of St. Petersburg are most susceptible to pollution by heavy metals, PAHs and active anthropogenic impact.

The aim of this work is to assess the sanitary-chemical and sanitary-microbiological composition of the alluvial territories of the 300th anniversary park of St. Petersburg, South Seaside Park, as well as a site free from development near Leninsky Prospekt. The following tasks were set:

- $\quad$ to investigate the morphometric organization and determine the taxonomic position of alluvial soils;

- to conduct research on sanitary-chemical indicators of alluvial territories;

- $\quad$ to conduct sanitary-microbiological and sanitary-parasitological studies;

- $\quad$ to evaluate the quality of soils in the study area using integrated indicators.

\section{Materials and methods}

The soil samples of alluvial territories of the city of St. Petersburg were selected in the territory of the 300th anniversary park of St. Petersburg, South Seaside Park, as well as in the area of alluvial territories near Leninsky Prospekt (Fig. 1). In St. Petersburg, alluvial land is carried out since its inception. At first, it was required to protect the city from flooding. Later, artificial areas were created for the construction of port facilities. Washed soils were actively used in the 1970s and 80s in green building, some of which have been cultivated for some 40 years now, and some of the abandoned lands that have been washed up undergo self-overgrowing. In total, for these years about 500 hectares were created by washing.

The sampled soils were isolated and sampled in the study areas, the sampling points correspond to different positions in the landscape.

The study areas belong to different functional zones of the city (recreational and industrial) in areas free from asphalt. The thickness of the studied soils depended on the depth of stratification by overcompacted soils. In the area of beaches, soils were selected from the upper horizons $(0-20 \mathrm{~cm})$. Sample preparation was carried out according to the standard procedure, air dry samples were sieved through a $1 \mathrm{~mm}$ sieve.

Laboratory analysis of soils were carried out in the Center for Hygiene and Epidemiology in the Leningrad Oblast in the Lomonosov in accordance with the basic requirement of the international standard ISO 9000. Laboratory determination of particle size distribution was carried out in accordance with WRB FAO (2015). The determination of the content of ( $\mathrm{Zn}, \mathrm{Cu}, \mathrm{Pb}, \mathrm{Ni}$, $\mathrm{Cd}$ ) and metalloids (As) in the soil was carried out in accordance with the method inversion voltammetry on TA analyzers. To extract heavy metals and metalloids, $1 \mathrm{M} \mathrm{HNO}_{3}$ was used. The $\mathrm{pH}$ of the salt suspension was determined by a potentiometric method with a glass electrode. The benzo[a]pyrene content was determined on a Fluorat-02 liquid chromatograph. The $\mathrm{pH}$ of the salt extract was determined by a potentiometric method with a glass 


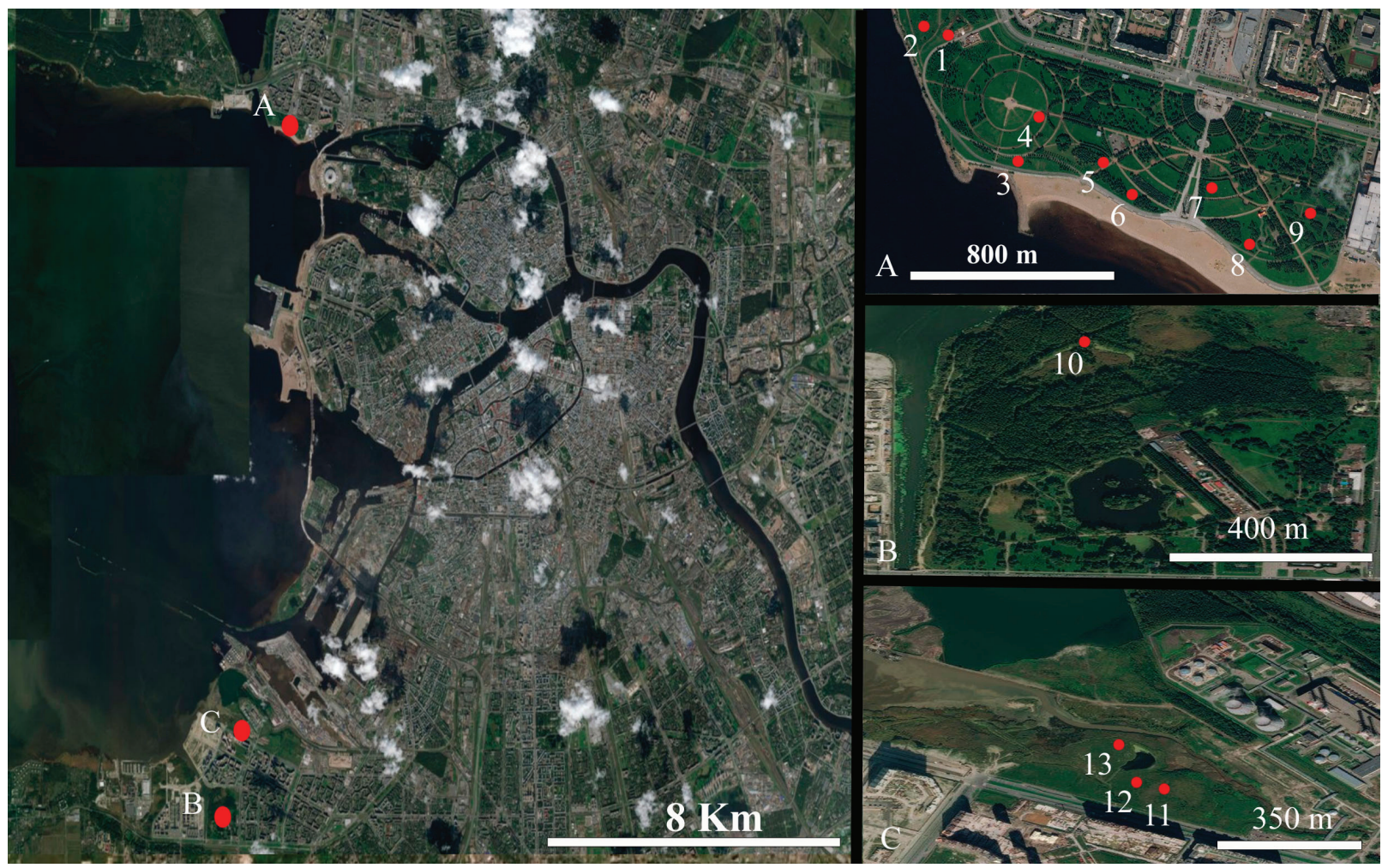

Fig. 1. The study area of St. Petersburg. A - 300th anniversary Park; B - South Seaside Park; C - alluvial territory near Leninsky Prospect

electrode using the Multitest IPL-301. The content of PP (petroleum product) in the soil was conducted on the fluorometric detector Fluorat 02-3M. The assessment of HM, bezo(a)pyrene and PP pollution was carried out by comparing the obtained data with existing hygienic standards and background contents. The soil contamination index with heavy metals and metalloids Zc was calculated according to SanPiN 4266-87 (Table 1).

The accuracy index (the limits of the relative error at a probability of $\mathrm{P}=0.95$ ) of determination for heavy metals and metalloids by this method is $\pm 30 \%$. The indicator of the accuracy of the determination of petroleum products is $\pm 34 \%$. The bezo(a)pyrene determination accuracy is $\pm 24 \%$. Measurements were performed in five replicates $(n=5)$ (MU 31-18 / 06; PND F 16.1.21-98; PND F 16.1: 2: 2.2: 3.39-03).

The of level of environmental danger of contamination of urban soils with a complex of heavy metals and metalloids was carried out based on the total chemical contamination index $(Z c)$ (SanPiN 4266-87; Vodyanitsky and Yakovlev, 2011). Calculation of $Z c$ index is performed using the following Eq (1-2).

$Z c=\sum_{i=1}^{n} K c-(n-1)$

where $K c$ - the concentration coefficient of the $i$-th chemical element, $n$ is the number equal to the number of elements entering the geochemical association.

$K c=\frac{C i}{C_{\text {back }}}$

where $\mathrm{Ci}$ - the actual content of the element, $C_{b a c k^{*}}{ }^{-}$geochemical background.

Table 1

Estimated scale of the danger of soil pollution by total pollution indicator (Zc) according to SanPiN 4266-87

\begin{tabular}{lll}
\hline Soil pollution category & $Z c$ & Changes in population health indicators in center of pollution \\
\hline Permissible & $<16$ & $\begin{array}{l}\text { The lowest level of morbidity in children and the minimum frequency of occurrence of functional } \\
\text { deviations }\end{array}$ \\
Moderately dangerous & $16-32$ & $\begin{array}{l}\text { Increase in overall morbidity } \\
\text { Dangerous }\end{array}$ \\
$32-128$ & $\begin{array}{l}\text { Increase in overall morbidity, the number of frequently ill children, children with chronic diseases, } \\
\text { impaired functional disorders of the cardiovascular system }\end{array}$ \\
Extremely dangerous & $>128$ & $\begin{array}{l}\text { The increase in the incidence of the child population, impaired reproductive function of women (an } \\
\text { increase in toxicosis during pregnancy, the number of premature births, stillbirths) }\end{array}$ \\
\hline
\end{tabular}


The geo-accumulation pollution index (Muller 1998) was also calculated. This index is widely used to study pollution levels of trace metals in soils. It enables the assessment of contamination by comparing current and pristine concentrations of the contaminants. Calculation of geo-accumulation index is performed using the following Eq (3).

Igeo $=\log _{2} \frac{C n}{k B n}$

where $\mathrm{Cn}$ is the concentration of the trace element in the enriched sample $\left(\mathrm{mg} \cdot \mathrm{kg}^{-1}\right) ; \mathrm{Bn}$ is the geochemistry background value of the same element in soil $\left(\mathrm{mg}^{\mathrm{kg}} \mathrm{kg}^{-1}\right) ; k$ is the factor introduced to minimize the effect of possible variations of soil background value due to lithogenic effects, the recommended value is 1.5. The degree of soil pollution is assessed according to seven contamination classes (Forstner et al., 1990) in order of increasing numerical value of the index as shown in Table 2.

Table 2

Classes of geo-chemical index according to Forster et al., 1990

\begin{tabular}{lll}
\hline $\begin{array}{l}\text { Igeo } \\
\text { class }\end{array}$ & $\begin{array}{l}\text { Igeo } \\
\text { value }\end{array}$ & Pollution level \\
\hline & Igeo $<0$ & Practically unpolluted \\
$0 \leq$ Igeo $\leq 1$ & Practically unpolluted to moderately polluted \\
$1 \leq$ Igeo $\leq 2$ & Moderately polluted \\
$2 \leq$ Igeo $\leq 3$ & Moderately polluted to highly polluted \\
$3 \leq$ Igeo $\leq 4$ & Highly polluted \\
$4 \leq$ Igeo $\leq 5$ & Highly polluted to extremely polluted \\
& Igeo $>5$ & Extremely polluted \\
\hline
\end{tabular}

The level of microbiological contamination of the studied soils was determined in accordance with SanPiN 2.1.7.1287-03, MU 31-18/06 according to the following indicators: Determination of Coli Bacteria in soil by membrane filtration (MR FTs 402204), determination of pathogenic enterobacteria of the genera Salmonella and Shigella (MR FTs 4022-04), determination of enterococci by the titration method (MR FTs 4022-04), soil analysis of helminth eggs by Vasilkova's method and Getter (MR FTs 402204), soil testing for intestinal protozoa cysts Padchenko Method (MR FTs 4022-04).

Correlation coefficients were calculated with $\mathrm{p}=0.05$.

\section{Results and discussion}

\subsection{Morphological characteristic of study soils}

The studied soils in alluvial territories in the 300th anniversary park of St. Petersburg were classified by Technosols. In the territory of South Seaside Park, a profile of newly formed soil formed on alluvial soil was described. Soil formation in alluvial territories is subordinate to the zonal factor of soil formation, in connection with this Podzol is formed. In the industrial zone, soils were also classified as Technosols, which is associated with a high anthropogenic impact in the area (Fig. 2). The morphological description of the studied soils is presented in Table 3.

The density of the solid phase is one of the fundamental characteristics of the soil, reflecting its mineralogical and chemical compositions (Ufimtseva et al., 2011). The content and distribution of particle size fractions affect the physicochemical and water-physical properties of soils, the nature of redox processes that determine the mobility and availability of elements in the soil profile and their migration (Chen et al., 2005). The density and particle size distribution of the studied soils are presented in Table 4.

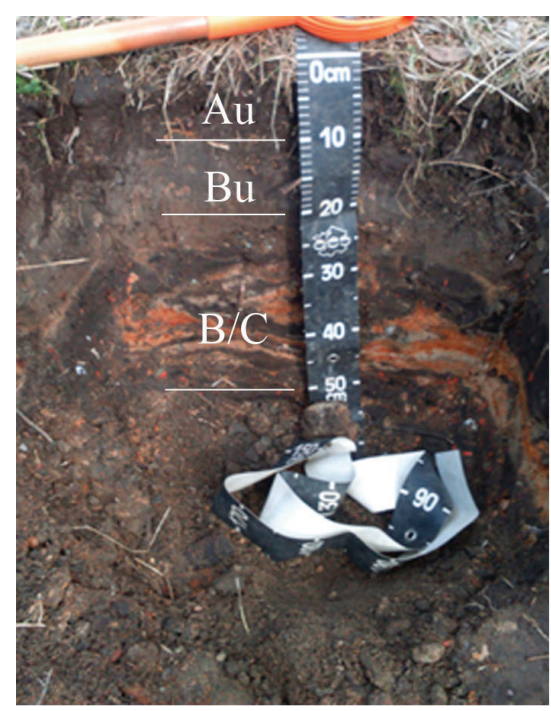

A

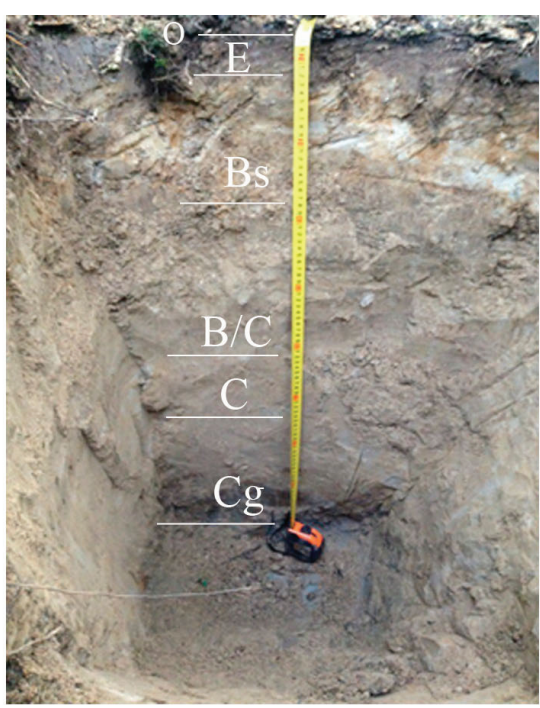

B

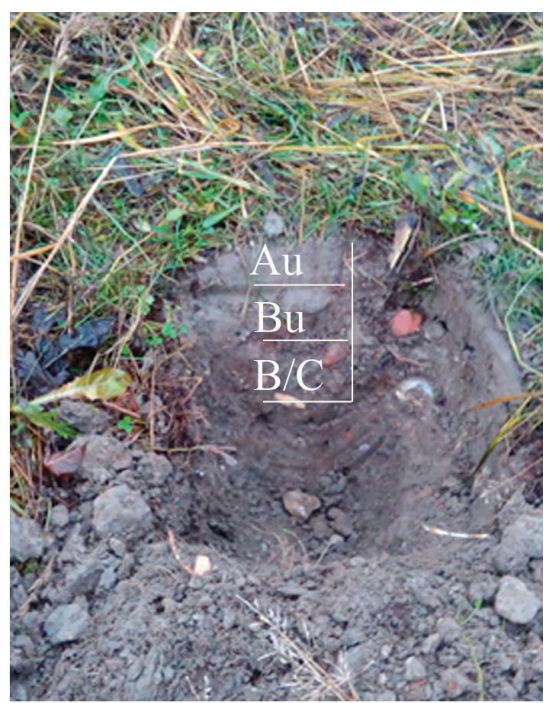

$\mathrm{C}$

Fig. 2. Morphological diversity of study soils. A - 300th anniversary park; B - South Seaside Park; C - Undeveloped area near Leninsky Prospekt 
Table 3

Description of the studied soil.

\begin{tabular}{|c|c|c|c|c|c|c|}
\hline Study area & Soil ID & Coordinates & Depth, cm & Horizon & Description & Soil name \\
\hline \multirow[t]{11}{*}{ 300th anniversary park } & 1 & $\begin{array}{l}59^{\circ} 59^{\prime} 08.00^{\prime \prime} \mathrm{N} \\
30^{\circ} 11^{\prime} 22.83^{\prime \prime} \mathrm{E}\end{array}$ & $0-10$ & $\mathrm{Au}$ & $\begin{array}{l}\text { Organic horizon with presence of urban } \\
\text { and other human-made materials }\end{array}$ & Technosols \\
\hline & 2 & $\begin{array}{l}59^{\circ} 59^{\prime} 08.77^{\prime \prime} \mathrm{N} \\
30^{\circ} 11^{\prime} 19.44^{\prime \prime} \mathrm{E}\end{array}$ & $0-10$ & $\mathrm{Au}$ & $\begin{array}{l}\text { Organic horizon with presence of urban } \\
\text { and other human-made materials }\end{array}$ & Technosols \\
\hline & 3 & $\begin{array}{l}59^{\circ} 58^{\prime} 57.95^{\prime \prime} \mathrm{N} \\
30^{\circ} 11^{\prime} 35.97^{\prime \prime} \mathrm{E}\end{array}$ & $0-10$ & $\mathrm{Au}$ & $\begin{array}{l}\text { Organic horizon with presence of urban } \\
\text { and other human-made materials }\end{array}$ & Technosols \\
\hline & & & $10-20$ & $\mathrm{Bu}$ & $\begin{array}{l}\text { Mineral horizon with presence of urban } \\
\text { and other human-made materials }\end{array}$ & \\
\hline & & & $20-50$ & $\mathrm{~B} / \mathrm{C}$ & Transition horizon to parent rock & \\
\hline & 4 & $\begin{array}{l}59^{\circ} 59^{\prime} 01.59^{\prime \prime} \mathrm{N} \\
30^{\circ} 11^{\prime} 37.82^{\prime \prime} \mathrm{E}\end{array}$ & $0-10$ & $\mathrm{Au}$ & $\begin{array}{l}\text { Organic horizon with presence of urban } \\
\text { and other human-made materials }\end{array}$ & Technosols \\
\hline & 5 & $\begin{array}{l}59^{\circ} 58^{\prime} 57.88^{\prime \prime} \mathrm{N} \\
30^{\circ} 11^{\prime} 49.25^{\prime \prime} \mathrm{E}\end{array}$ & $0-10$ & $\mathrm{Au}$ & $\begin{array}{l}\text { Organic horizon with presence of urban } \\
\text { and other human-made materials }\end{array}$ & Technosols \\
\hline & 6 & $\begin{array}{l}59^{\circ} 58^{\prime} 55.33^{\prime \prime} \mathrm{N} \\
30^{\circ} 11^{\prime} 54.04^{\prime \prime} \mathrm{E}\end{array}$ & $0-10$ & $\mathrm{Au}$ & $\begin{array}{l}\text { Organic horizon with presence of urban } \\
\text { and other human-made materials }\end{array}$ & Technosols \\
\hline & 7 & $\begin{array}{l}59^{\circ} 58^{\prime} 55.94^{\prime \prime} \mathrm{N} \\
30^{\circ} 12^{\prime} 06.94^{\prime \prime} \mathrm{E}\end{array}$ & $0-10$ & $\mathrm{Au}$ & $\begin{array}{l}\text { Organic horizon with presence of urban } \\
\text { and other human-made materials }\end{array}$ & Technosols \\
\hline & 8 & $\begin{array}{l}59^{\circ} 58^{\prime} 50.69^{\prime \prime} \mathrm{N} \\
30^{\circ} 12^{\prime} 13.97^{\prime \prime} \mathrm{E}\end{array}$ & $0-10$ & $\mathrm{Au}$ & $\begin{array}{l}\text { Organic horizon with presence of urban } \\
\text { and other human-made materials }\end{array}$ & Technosols \\
\hline & 9 & $\begin{array}{l}59^{\circ} 58^{\prime} 53.86^{\prime \prime} \mathrm{N} \\
30^{\circ} 12^{\prime} 23.32^{\prime \prime} \mathrm{E}\end{array}$ & $0-10$ & $\mathrm{Au}$ & $\begin{array}{l}\text { Organic horizon with presence of urban } \\
\text { and other human-made materials }\end{array}$ & Technosols \\
\hline \multirow[t]{5}{*}{ South Seaside Park } & 10 & $\begin{array}{l}59^{\circ} 51^{\prime} 20.36^{\prime \prime} \mathrm{N} \\
30^{\circ} 09^{\prime} 55.78^{\prime \prime} \mathrm{E}\end{array}$ & $\begin{array}{l}0-3 \\
3-12\end{array}$ & $\begin{array}{l}\mathrm{O} \\
\mathrm{E}\end{array}$ & $\begin{array}{l}\text { Undecomposed litter } \\
\text { Mineral horizon, loss of silicate clay, iron, } \\
\text { aluminium. }\end{array}$ & Podzol \\
\hline & & & $12-29$ & Bs & $\begin{array}{l}\text { Mineral horizon with illuvial accumulation } \\
\text { of sesquioxides }\end{array}$ & \\
\hline & & & $29-51$ & $\mathrm{~B} / \mathrm{C}$ & Transition horizon to parent rock & \\
\hline & & & $51-63$ & $\mathrm{C}$ & Parent material & \\
\hline & & & $63-91$ & $\mathrm{Cg}$ & Parent material with stagnic conditions & \\
\hline \multirow[t]{9}{*}{$\begin{array}{l}\text { Undeveloped area near } \\
\text { LeninskyProspekt }\end{array}$} & 11 & $\begin{array}{l}59^{\circ} 52^{\prime} 06.67^{\prime \prime} \mathrm{N} \\
30^{\circ} 10^{\prime} 34.09^{\prime \prime} \mathrm{E}\end{array}$ & $0-10$ & $\mathrm{Au}$ & $\begin{array}{l}\text { Organic horizon with presence of urban } \\
\text { and other human-made materials }\end{array}$ & Technosols \\
\hline & & & $10-20$ & $\mathrm{Bu}$ & $\begin{array}{l}\text { Mineral horizon with presence of urban } \\
\text { and other human-made materials }\end{array}$ & \\
\hline & & & $20-30$ & $\mathrm{~B} / \mathrm{C}$ & Transition horizon to parent rock & \\
\hline & 12 & $\begin{array}{l}59^{\circ} 52^{\prime} 07.18^{\prime \prime} \mathrm{N} \\
30^{\circ} 10^{\prime} 30.85^{\prime \prime} \mathrm{E}\end{array}$ & $0-10$ & $\mathrm{Au}$ & $\begin{array}{l}\text { Organic horizon with presence of urban } \\
\text { and other human-made materials }\end{array}$ & Technosols \\
\hline & & & $10-20$ & $\mathrm{Bu}$ & $\begin{array}{l}\text { Mineral horizon with presence of urban } \\
\text { and other human-made materials }\end{array}$ & \\
\hline & & & $20-30$ & $\mathrm{~B} / \mathrm{C}$ & Transition horizon to parent rock & \\
\hline & 13 & $\begin{array}{l}59^{\circ} 52^{\prime} 11.64^{\prime \prime} \mathrm{N} \\
30^{\circ} 10^{\prime} 27.91^{\prime \prime} \mathrm{E}\end{array}$ & $0-10$ & $\mathrm{Au}$ & $\begin{array}{l}\text { Organic horizon with presence of urban } \\
\text { and other human-made materials }\end{array}$ & Technosols \\
\hline & & & $10-20$ & $\mathrm{Bu}$ & $\begin{array}{l}\text { Mineral horizon with presence of urban } \\
\text { and other human-made materials }\end{array}$ & \\
\hline & & & $20-30$ & $\mathrm{~B} / \mathrm{C}$ & Transition horizon to parent rock & \\
\hline
\end{tabular}


Table 4

Physical properties of study soils. Soil ID correspond to Table 3

\begin{tabular}{|c|c|c|c|c|c|c|}
\hline \multirow[t]{2}{*}{ Soil ID } & \multirow{2}{*}{$\begin{array}{l}\text { Depth, } \\
\mathrm{cm}\end{array}$} & \multicolumn{3}{|c|}{ Granulometric composition, \% } & \multirow{2}{*}{$\begin{array}{l}\text { Solid } \\
\text { phase } \\
\text { density, } \\
\mathrm{g} \cdot \mathrm{cm}^{-3}\end{array}$} & \multirow{2}{*}{$\begin{array}{l}\text { Density, } \\
\mathrm{g} \cdot \mathrm{cm}^{-3}\end{array}$} \\
\hline & & Sand & Clay & Dust & & \\
\hline \multicolumn{7}{|c|}{ 300th anniversary park, Technosols } \\
\hline 1 & $0-10$ & 53 & 25 & 22 & 2.67 & 1.00 \\
\hline 2 & $0-10$ & 59 & 28 & 13 & 2.72 & 1.38 \\
\hline \multirow[t]{3}{*}{3} & $0-10$ & 67 & 21 & 12 & 2.78 & 1.02 \\
\hline & $10-20$ & 60 & 23 & 17 & 2.59 & 0.82 \\
\hline & $20-50$ & 57 & 22 & 21 & 2.63 & 0.99 \\
\hline 4 & $0-10$ & 71 & 20 & 9 & 2.65 & 0.67 \\
\hline 5 & $0-10$ & 64 & 16 & 20 & 2.67 & 0.62 \\
\hline 6 & $0-10$ & 73 & 17 & 10 & 2.71 & 0.77 \\
\hline 7 & $0-10$ & 63 & 24 & 13 & 2.68 & 1.06 \\
\hline 8 & $0-10$ & 71 & 19 & 10 & 2.73 & 0.91 \\
\hline 9 & $0-10$ & 71 & 17 & 12 & 2.72 & 0.85 \\
\hline \multicolumn{7}{|c|}{ South Seaside Park, Podzol } \\
\hline \multirow[t]{6}{*}{10} & $0-3$ & 53 & 25 & 22 & 2.74 & 0.58 \\
\hline & 3-12 & 69 & 16 & 17 & 2.78 & 1.03 \\
\hline & $12-29$ & 68 & 22 & 10 & 2.76 & 1.05 \\
\hline & 29-51 & 71 & 14 & 17 & 2.74 & 1.04 \\
\hline & 51-63 & 69 & 19 & 12 & 2.71 & 0.80 \\
\hline & 63-91 & 41 & 48 & 11 & 2.67 & 1.32 \\
\hline
\end{tabular}

Undeveloped area near Leninsky Prospekt, Technosols

\begin{tabular}{lllllll}
\hline 11 & $0-10$ & 68 & 25 & 7 & 2.71 & 1.41 \\
& $10-20$ & 78 & 12 & 10 & 2.69 & 1.05 \\
& $20-30$ & 73 & 19 & 8 & 2.67 & 0.85 \\
\hline 12 & $0-10$ & 59 & 30 & 11 & 2.64 & 1.12 \\
& $10-20$ & 67 & 22 & 11 & 2.63 & 0.62 \\
& $20-30$ & 63 & 29 & 8 & 2.57 & 0.77 \\
\hline 13 & $0-10$ & 71 & 20 & 9 & 2.67 & 1.09 \\
& $10-20$ & 64 & 25 & 11 & 2.64 & 1.05 \\
& $20-30$ & 68 & 20 & 12 & 2.62 & 0.62 \\
\hline
\end{tabular}

The density of the solid phase in the studied soil samples ranges from 2.57 to $2.78 \mathrm{~g} \cdot \mathrm{cm}^{-3}$, increasing in the middle and bottom parts of the profile. According to Stroganova, the density of the solid phase of soils in urban soils of Moscow varies from 2.47 to $2.73 \mathrm{~g} \cdot \mathrm{cm}^{-3}$ (Shikhova, 2005). The data shown in Table 3 show that the soil had a density from 0.58 to $1.41 \mathrm{~g} \cdot \mathrm{cm}^{-3}$ with the highest values in the alluvial soils, in the Cg horizon in the South Seaside park, where is excessive compaction due to eluvial-illuvial processes occurs. In contrast to the United States, where $2 / 3$ of urban soil samples have a density more than $1.6 \mathrm{~g} \cdot \mathrm{cm}^{-3}$ (Inman and Parker, 1978), none of our samples exceeded 1.41 $\mathrm{g} \cdot \mathrm{cm}^{-3}$, which indicates less compaction.
All territories are subject to anthropogenic impact, in parks it is expressed as recreational services (a large flow of people), which results in soil compaction, which is especially noticeable in the upper soil layers (Scharenbroch et al., 2005). The density of the upper soil horizon on the territory of Leninsky Prospekt is $1.41 \mathrm{~g}^{\mathrm{cm}} \mathrm{cm}^{-3}$, which is the maximum value and can be associated with the frequent use of the undeveloped zone as an easily accessible and unattended recreational zone. Most of the studied soils are sandy loam. In areas where a change in physicochemical conditions occurs, such as in soil examined in the South Seaside Park, characterized by a heavy granulometric composition, the formation of geochemical barriers is possible due to the stagnant type of water regime. These conditions contribute to the accumulation of trace metals, iron and aluminum oxides. In some areas of the studied territories stagnic conditions is observed. The high content of dusty particles in the soil gives them low water permeability, and the presence of a small amount of clay and silty particles increases the water-holding and absorption capacity and leads to waterlogging conditions in the territory.

\subsection{Heavy metals in study soils}

The content of HM in urban soils is caused by different sources: 1) parent rocks; 2) alluvial soils; 3) atmospheric precipitation, etc. (Sodango et al., 2018). The transfer and accumulation of atmospheric aerosols and technogenic dust is adjusted by the height and character of the buildings, the between the buildings, the ratio of asphalt and green areas (Kapelkina, 2010b). The data of heavy metals and metalloids content are presented in Table 5.

From the studied heavy metals and metalloids content, 35\% of the samples don't correspond to the standard values. The highest concentrations of pollutants were found in soils of alluvial territories near Leninsky Prospekt. In almost all soil samples, maximum permissible concentration (MPC) is exceeded for $\mathrm{Cu}, \mathrm{Pb}, \mathrm{Ni}, \mathrm{Zn}$. For St. Petersburg, there is an acute problem of soil contamination with zinc and lead, $42.3 \%$ of the samples taken during the study are characterized by excess MPC. On the territory of St. Petersburg, the main sources of soil pollution by HM are emissions from glass, paint and varnish industries. In addition, high levels of lead pollution are noted near highway. Significant amounts of this element and other heavy metals and metalloids accumulate in the roadside at a distance of $30 \mathrm{~m}$ from the road (Sezgin et al., 2003).

A study of the distribution of HM along the soil profile showed their migration and accumulation in the bottom horizons, which is clearly seen in lead and cadmium, for the territories of Leninsky Prospekt and the section in South Seaside Park. The remaining elements found in the section of the South Seaside Park are characterized by an uneven distribution of chemical elements in different genetic horizons. An increased content of HM in the O horizon is noted, then a decrease in the concentration in the E, Bs horizons, and increase in the in the $\mathrm{B} / \mathrm{C}$ and $\mathrm{C}$ horizons, which is most likely due to the accumulation of chemical elements here due to the presence of water border in the underlying horizon $\mathrm{Cg}$, as well as an increase in $\mathrm{pH}$ and a change in acid conditions (Sposito, 1989), which is the reason for the formation of a geochemical barrier here. 
Table 5

The content of heavy metals and metalloids in study soils. Soil ID correspond to Table 3

\begin{tabular}{|c|c|c|c|c|c|c|c|c|}
\hline \multirow[t]{2}{*}{ Soil ID } & \multirow[t]{2}{*}{ Depth, cm } & \multirow[t]{2}{*}{$\mathrm{pH}$} & $\mathrm{Cu}$ & $\mathrm{Pb}$ & $\mathrm{Cd}$ & As & $\mathrm{Ni}$ & $\mathrm{Zn}$ \\
\hline & & & \multicolumn{6}{|c|}{$\mathrm{mg} \cdot \mathrm{kg}^{-1}$} \\
\hline \multicolumn{9}{|c|}{ 300th anniversary park, Technosols } \\
\hline 1 & $0-20$ & 7.07 & 1.90 & 3.00 & 0.10 & 1.06 & 3.50 & 32.1 \\
\hline 2 & $0-20$ & 7.16 & - & 11.8 & - & 1.17 & 4.00 & 24.7 \\
\hline \multirow[t]{3}{*}{3} & $0-10$ & 7.58 & - & 8.00 & - & 1.12 & 4.10 & 32.0 \\
\hline & $10-20$ & 7.76 & 3.20 & 4.00 & 0.13 & 1.26 & 3.20 & 21.9 \\
\hline & $20-50$ & 7.90 & 4.10 & 3.00 & 0.10 & 1.3 & 3.00 & 27.6 \\
\hline 4 & $0-20$ & 7.34 & - & 1.40 & - & $<1$ & 2.90 & 19.0 \\
\hline 5 & $0-20$ & 7.68 & 2.80 & 7.00 & - & $<1$ & 3.00 & 18.0 \\
\hline 6 & $0-20$ & 6.50 & 3.22 & 9.00 & 0.12 & $<1$ & 3.80 & 14.5 \\
\hline 7 & $0-20$ & 6.20 & 4.56 & 11.4 & 0.11 & 1.09 & 3.50 & 18.6 \\
\hline 8 & $0-20$ & 6.15 & 2.30 & 2.80 & 0.10 & $<1$ & 2.80 & 19.4 \\
\hline 9 & $0-20$ & 6.54 & 2.90 & 4.30 & 0.13 & $<1$ & 2.90 & 38.0 \\
\hline Min. & - & 6.15 & 1.90 & 1.40 & 0.10 & 1.06 & 2.80 & 14.5 \\
\hline Max. & - & 7.90 & 4.56 & 11.8 & 0.13 & 1.30 & 4.10 & 38.0 \\
\hline Mean & - & - & 3.12 & 5.97 & 0.11 & 1.17 & 3.34 & 24.2 \\
\hline S.D. & - & 0.61 & 0.82 & 3.48 & 0.01 & 0.09 & 0.45 & 7.04 \\
\hline \multicolumn{9}{|c|}{ South Seaside Park, Podzol } \\
\hline \multirow[t]{6}{*}{10} & $0-3$ & 6.14 & 4.30 & 9.20 & 0.12 & $<1$ & 9.30 & 18.5 \\
\hline & $3-12$ & 6.60 & 3.34 & 2.20 & 0.40 & $<1$ & 4.20 & 22.1 \\
\hline & $12-29$ & 6.90 & 2.95 & 3.10 & 0.15 & $<1$ & 3.50 & 23.0 \\
\hline & $29-51$ & 7.07 & 3.06 & 3.60 & 0.17 & $<1$ & 2.90 & 24.7 \\
\hline & $51-63$ & 7.38 & 2.47 & 3.60 & 0.11 & $<1$ & 3.80 & 31.8 \\
\hline & $63-91$ & 7.60 & 2.04 & 2.00 & - & $<1$ & 3.00 & 17.0 \\
\hline Min. & - & 6.14 & 2.04 & 2.00 & 0.11 & 0.00 & 2.90 & 17.0 \\
\hline Max. & - & 7.60 & 4.30 & 9.20 & 0.40 & 0.00 & 9.30 & 31.8 \\
\hline Mean & - & - & 3.03 & 3.95 & 0.19 & - & 4.45 & 22.9 \\
\hline S.D. & - & 0.48 & 0.71 & 2.43 & 0.11 & - & 2.21 & 4.78 \\
\hline \multicolumn{9}{|c|}{ Undeveloped area near Leninsky Prospekt, Technosols } \\
\hline \multirow[t]{3}{*}{11} & $0-10$ & 8.04 & 3.12 & 46.8 & 0.10 & 3.13 & 18.9 & 87.0 \\
\hline & $10-20$ & 7.39 & 12.60 & 52.3 & 0.14 & 2.08 & 17.3 & 79.3 \\
\hline & $20-30$ & 7.78 & 7.98 & 78.0 & 0.19 & $<1$ & 18.0 & 65.1 \\
\hline \multirow[t]{3}{*}{12} & $0-10$ & 7.26 & 3.64 & 45.8 & 0.13 & 2.47 & 19.4 & 79.1 \\
\hline & $10-20$ & 6.40 & 4.20 & 53.2 & 0.15 & 1.56 & 20.1 & 40.0 \\
\hline & $20-30$ & 7.85 & 5.50 & 67.2 & 0.24 & - & 18.7 & 39.0 \\
\hline \multirow[t]{3}{*}{13} & $0-10$ & 7.23 & 4.34 & 74.9 & 0.12 & $<1$ & 21.0 & 69.5 \\
\hline & $10-20$ & 6.98 & 1.50 & 10.7 & 0.16 & $<1$ & 17.3 & 67.0 \\
\hline & $20-30$ & 8.01 & - & 56.6 & 0.18 & $<1$ & 17.8 & 45.3 \\
\hline Min. & - & 6.40 & 1.50 & 10.7 & 0.10 & 1.56 & 17.3 & 39.0 \\
\hline Max. & - & 8.04 & 12.6 & 78.0 & 0.24 & 3.13 & 21.0 & 87.0 \\
\hline Mean & - & - & 5.36 & 53.9 & 0.16 & 2.31 & 18.7 & 63.5 \\
\hline S.D. & - & 0.51 & 3.25 & 18.8 & 0.04 & 0.57 & 1.20 & 16.9 \\
\hline $\mathrm{MPC}^{*}$ & & & 3 & 32 & 0.5 & 2 & 4 & 23 \\
\hline Backgro & & & 8 & 6 & 0.05 & 1.5 & 6 & 28 \\
\hline
\end{tabular}

“_“ not detected, MPC - maximum permissible concentration

*MU 2.1.7.730-99, **Sorokin et al., 2012 
The surface horizon contains less HM, which can be associated with their leaching and with the fact that plants extract heavy metals and metalloids by the root system and accumulate them in the biomass (Suman et al., 2018). For a comprehensive analysis of the degree of chemical pollution of the studied soils, the index Zc and Igeo were calculated. The results are presented in Table 6.

From the studied samples, the highest indicators of total soil pollution are noted in samples taken in areas of alluvial territories near Leninsky Prospekt (№ 11-13). Three samples belong to the moderately dangerous pollution category, while in the territory of the 300th anniversary park of St. Petersburg and the South Seaside park, none of the samples exceeds the permissible pollution category. The Igeo index varies quite widely among the studied horizons. The most severe pollution is presented in the undeveloped area near Leninsky Prospekt. Hazardous concentrations are noted for lead, cadmium and nickel. That is due to the proximity of this zone to the power plant. The high pollution level of the territory is caused by lead (Igeo $=8.03$ ), and its proximity to the highway can affect its accumulation.

Table 6

Soil pollution index. Soil ID correspond to Table 3

\begin{tabular}{|c|c|c|c|c|c|c|c|c|}
\hline \multirow[t]{2}{*}{ Soil ID } & \multirow{2}{*}{$\begin{array}{l}\text { Depth, } \\
\text { cm }\end{array}$} & \multicolumn{6}{|l|}{ Igeo } & \multirow[t]{2}{*}{ Zc index } \\
\hline & & $\mathrm{Cu}$ & $\mathrm{Pb}$ & $\mathrm{Cd}$ & As & $\mathrm{Ni}$ & $\mathrm{Zn}$ & \\
\hline \multicolumn{9}{|c|}{ 300th anniversary park, Technosols } \\
\hline 1 & $0-20$ & -2.65 & -1.58 & 0.41 & -1.08 & -1.36 & -0.38 & Permissible \\
\hline 2 & $0-20$ & 0 & 0.39 & 0 & -0.94 & -1.16 & -0.76 & Permissible \\
\hline \multirow[t]{3}{*}{3} & $0-10$ & -3.45 & -2.92 & -1.21 & -2.63 & -4.21 & -1.93 & Permissible \\
\hline & $10-20$ & & & & & & & Permissible \\
\hline & $20-50$ & & & & & & & Permissible \\
\hline 4 & $0-20$ & $\mathrm{n} / \mathrm{a}$ & -2.68 & $\mathrm{n} / \mathrm{a}$ & $\mathrm{n} / \mathrm{a}$ & -1.63 & -1.14 & Permissible \\
\hline 5 & $0-20$ & -2.09 & -0.36 & $\mathrm{n} / \mathrm{a}$ & $\mathrm{n} / \mathrm{a}$ & -1.58 & -1.22 & Permissible \\
\hline 6 & $0-20$ & -1.89 & $\mathrm{n} / \mathrm{a}$ & 0.67 & $\mathrm{n} / \mathrm{a}$ & -1.24 & -1.53 & Permissible \\
\hline 7 & $0-20$ & -1.39 & 0.34 & 0.55 & -1.04 & -1.36 & -1.17 & Permissible \\
\hline 8 & $0-20$ & -2.38 & -1.68 & 0.41 & $\mathrm{n} / \mathrm{a}$ & -1.68 & -1.11 & Permissible \\
\hline 9 & $0-20$ & -2.04 & -1.06 & 0.79 & $\mathrm{n} / \mathrm{a}$ & -1.63 & -0.14 & Permissible \\
\hline \multicolumn{9}{|c|}{ South Seaside Park, Podzol } \\
\hline \multirow[t]{6}{*}{10} & $0-3$ & -12.15 & -8.35 & 5.82 & $\mathrm{n} / \mathrm{a}$ & -6.87 & -5.45 & Permissible \\
\hline & $3-12$ & & & & & & & Permissible \\
\hline & $12-29$ & & & & & & & Permissible \\
\hline & $29-51$ & & & & & & & Permissible \\
\hline & $51-63$ & & & & & & & Permissible \\
\hline & $63-91$ & & & & & & & Permissible \\
\hline \multicolumn{9}{|c|}{ Undeveloped area near LeninskyProspekt, Technosols } \\
\hline \multirow[t]{3}{*}{11} & $0-10$ & -2.46 & 8.03 & 2.65 & 0.36 & 3.01 & 2.59 & Permissible \\
\hline & $10-20$ & & & & & & & Permissible \\
\hline & $20-30$ & & & & & & & $\begin{array}{l}\text { Moderately } \\
\text { dangerous }\end{array}$ \\
\hline \multirow[t]{3}{*}{12} & $0-10$ & -4.36 & 7.81 & 3.47 & -0.39 & 3.32 & 0.73 & Permissible \\
\hline & $10-20$ & & & & & & & Permissible \\
\hline & $20-30$ & & & & & & & $\begin{array}{l}\text { Moderately } \\
\text { dangerous }\end{array}$ \\
\hline \multirow[t]{3}{*}{13} & $0-10$ & -4.46 & 5.95 & 3.03 & $\mathrm{n} / \mathrm{a}$ & 3.14 & 1.51 & Permissible \\
\hline & $10-20$ & & & & & & & Permissible \\
\hline & $20-30$ & & & & & & & $\begin{array}{l}\text { Moderately } \\
\text { dangerous }\end{array}$ \\
\hline
\end{tabular}

*n/a-not available (low concentration) 
3.3. Monitoring of bezo(a)pyrene and petroleum product in the soils of the alluvial territories of St. Petersburg

Among the priority pollutants of the urban environment, one of the leading places is occupied by polycyclic aromatic hydrocarbons (PAHs) - high molecular weight organic compounds of the benzene series, differing in the number of benzene rings from 2 to 7 . Some PAHs are considered super pollutants of the natural environment and among them 16 compounds are included by the European Union and the Agency US Environmental Protection Agency (US EPA) on the standard list of priority toxicants (Zelincova and Wenzl, 2015). In Russia, rationing the content and indication of carcinogenic PAHs in soils during monitoring of the urban environment is carried out only for one compound - benzo[a]pyrene, the maximum permissible concentration of which is $0.02 \mathrm{mg} \cdot \mathrm{kg}^{-1}$ in soils (MU 2.1.7.730-99).

3,4-benzo[a]pyrene is a highly toxic, carcinogenic and mutagenic substance classified as, has good penetration into the cells of living organisms and has the property of bioaccumulation (Abdel-Shafy and Mansour, 2016). 3,4-benzo[a]pyrene is formed as a by-product of the thermal processing of organic raw materials and fuel combustion. The content of benzo[a]pyrene in the gases of thermal power plant boilers is from 1 to $4 \mu \mathrm{g} / 100$ $\mathrm{m}^{3}$, fuel oil from 2 to $40 \mu \mathrm{g} / 100 \mathrm{~m}^{3}$, coal from 30 to $140 \mu \mathrm{g} / 100 \mathrm{~m}^{3}$ (Mikhailova et al., 2016).

The "idle move", "acceleration" and "braking" from cars contribute to increased emission of concentrations of benzo[a]pyrene with the exhaust gases of the gasoline engine $-4000 \mu \mathrm{g} / 100 \mathrm{~m}^{3}, 10.000 \mu \mathrm{g} / 100 \mathrm{~m}^{3}$ and $28.000 \mu \mathrm{g} / 100 \mathrm{~m}^{3}$, respectively (Mikhailova et al., 2016). It is estimated that 100 grams of used tires contain up to $1.2 \mathrm{mg}$ of benzo[a]pyrene. Each kilometer of the route annually produces 30 kilograms of finely divided particles that settle on the soil. The main depot for benzo[a]pyrene in urban landscapes are soils with well-defined barrier functions that contribute to the fixation of PAHs in surface horizons (Mikhailova et al., 2016; Nikiforova and Kosheleva, 2011). The content of benzo[a]pyrene from study soils are presented in Table 7.

The data obtained indicate that greatest contribution to the total level of soil pollution in St. Petersburg is made by 3,4-benzo[a]pyrene (concentrations up to $34 \mathrm{MPC}$ ). Maximum excesses were observed in the surface horizons on the undeveloped territory of Leninsky Prospekt, where the highway and the South-Western power plant are placed nearby. The increased content of PAHs is characteristic of soils located in an area with a high degree of urbanization, a large technogenic load due to industrial production. It was found that in soils it is accumulated mainly in layers of $0-10$ and $10-20 \mathrm{~cm}$. Deeper than $20 \mathrm{~cm}$ from the surface, benzo[a]pyrene was found with a content of not more than $0.28 \mu \mathrm{g} \cdot \mathrm{kg}^{-1}$, which indicates a low migration ability of the PAHs. In general, according to studies (Shamilishvily et al., 2018), the highest concentrations of benzo[a]pyrene are observed in the surface layers of soils and this is probably due to the fact that humus horizons containing the largest amount of organic substances have a higher sorption capacity. However, we also found benzo[a]pyrene in a deeper horizon $(51-63 \mathrm{~cm})$ in the amount of $13.4 \%\left(0.39 \mu \mathrm{g} \cdot \mathrm{kg}^{-1}\right)$ of the total content in the section of the South Seaside Park.

In the residental areas, as well as in the parks, the mass concentrations of all types of PAHs are much less, but the duration of exposure to the pollution source, as well as the fact that PAHs are carried mainly by air currents, lead to an increase in the content of PAHs in soils (Lodygin et al., 2008; Syed et al., 2017). Therefore, in the South Seaside Park and the 300th anniversary park, we can observe the excess of the MPC to 7 and 9, respectively. These excesses may be associated with air emissions from urban transport and industry.

Table 7

The content of bezo(a)pyrene in the soils of the alluvial territories of St. Petersburg. Soil ID correspond to Table 3.

\begin{tabular}{|c|c|c|c|}
\hline Soil ID & Depth, cm & $\begin{array}{l}\text { Content of } \\
\text { benzo[a]pyrene } \mu \mathrm{g} \cdot \mathrm{kg}^{-1}\end{array}$ & $\begin{array}{l}\text { Content of } \\
\text { MPC }\end{array}$ \\
\hline \multicolumn{4}{|c|}{ 300th anniversary park, Technosols } \\
\hline 1 & $0-20$ & 185 & 9.0 \\
\hline 2 & $0-20$ & 61 & 3.0 \\
\hline \multirow[t]{3}{*}{3} & $0-10$ & 43 & 2.0 \\
\hline & $10-20$ & 33 & 1.5 \\
\hline & $20-50$ & 4.0 & 0.2 \\
\hline 4 & $0-20$ & 171 & 8.5 \\
\hline 5 & $0-20$ & 59 & 3.0 \\
\hline 6 & $0-20$ & 44 & 2.0 \\
\hline 7 & $0-20$ & 40 & 2.0 \\
\hline 8 & $0-20$ & 75 & 3.5 \\
\hline 9 & $0-20$ & 158 & 8.0 \\
\hline \multicolumn{4}{|c|}{ South Seaside Park, Podzol } \\
\hline \multirow[t]{6}{*}{10} & $0-3$ & 140 & 7.0 \\
\hline & $3-12$ & 102 & 5.0 \\
\hline & $12-29$ & 3.0 & 0.15 \\
\hline & $29-51$ & 5.0 & 0.25 \\
\hline & 51-63 & 39 & 2.0 \\
\hline & $63-91$ & 2.0 & 0.1 \\
\hline \multicolumn{4}{|c|}{ Undeveloped area near Leninsky Prospekt, Technosols } \\
\hline \multirow[t]{3}{*}{11} & $0-10$ & 619 & 31 \\
\hline & $10-20$ & 538 & 27 \\
\hline & $20-30$ & 6.0 & 0.3 \\
\hline \multirow[t]{3}{*}{12} & $0-10$ & 682 & 34 \\
\hline & $10-20$ & 604 & 30 \\
\hline & $20-30$ & 28 & 1.5 \\
\hline \multirow[t]{3}{*}{13} & $0-10$ & 537 & 27 \\
\hline & $10-20$ & 411 & 24 \\
\hline & $20-30$ & 4.0 & 0.2 \\
\hline
\end{tabular}

MPC - maximum permissible concentration 
The most effective decomposition of PAHs occurs in acidic soils. In the soil with $\mathrm{pH} 4.5$ in the first 10 days from 95 to $99 \%$ of the benzo[a]pyrene is destroyed, while in soil with a $\mathrm{pH}$ of 7.2 - from 18 to $80 \%$ (Gabov et al., 2004). This can also be observed in the studied parks, where the $\mathrm{pH}$ is lower than in the area of Leninsky Prospekt. In the absence of UV radiation and strong chemical oxidants, the main role in the processes of PAH degradation belongs to biological systems. Hundreds of varieties of bacteria, fungi, and higher plants were identified that used PAHs as a carbon-containing substrate to provide themselves with free energy.

The increased PAH contents in the soils of St. Petersburg are close to their levels in a number of urban soils in Moscow (Nikiforova and Kosheleva, 2011). Comparing with the results of the study of the soils of Vasilievsky Island, St. Petersburg (Lodygin et al., 2008), we can conclude that the results obtained are generally in good agreement for parks and areas with a characteristic high traffic load.

The development of the oil and gas sector in St. Petersburg may lead to environmental pollution by petroleum products (PP). In general, oil pollution has a significant effect on microbiological and biochemical processes in the soil; with a high degree of oil pollution, the vital activity of most plants, fungi, and microorganisms, including their enzymatic activity, is inhibited (Gabov et al., 2007). In the process of interaction of pollutant with soil, the qualitative and quantitative composition of microbiocenosis changes. Soils saturated with petroleum products lose their ability to absorb and retain moisture (Hewelke et al., 2018). Data on the content of petroleum products in the studied soils are presented in Table 8.

As a result, none of the studied soil samples revealed an excess of the MPC for the content of petroleum products. However, it should be noted that large concentrations of PP in soils located in the 300th anniversary park in comparison with other sites. The lowest content of PP is noted in soil samples taken in areas of alluvial territories near Leninsky Prospekt. The low concentrations determined during the studies are most likely due to the fact that the oxidation of petroleum products begins immediately after it enters the soil (Hewelke et al., 2018). Summarizing data on the content of hexane-soluble PPs in the soil it can be noted that $3.8 \%$ of the samples do not correspond to the background values (Shakhverdov and Shakhverdova, 2015), however, all concentrations agree the requirements of the current standard, which makes it possible to classify the study areas as "acceptable pollution levels" (Ministry of the Environment..., 1993), which is correspond to Sorokin (2012), where the study areas are assigned to zones with a content below $250 \mathrm{mg} \cdot \mathrm{kg}^{-1}$.

\subsection{Microbiological properties of study soils}

Biological soil contamination is the result of the accumulation in the soil of pathogens of infectious and invasive diseases, as well as insects and ticks, carriers of pathogens of human, animal and plant diseases in quantities. It represents a potential danger to the health living organisms (MU 2.1.7.730-99). To assess the degree of biological pollution of soils, sanitary-bacteriological and sanitary-parasitological indicators are used (Tab. 9).
Table 8

The content of petroleum products in alluvial soils of St. Petersburg. Soil ID correspond to Table 3

\begin{tabular}{|c|c|c|}
\hline Soil ID & Depth, cm & $\begin{array}{l}\text { Content of petroleum } \\
\text { products, } \mathrm{mg} \mathrm{kg}^{-1}\end{array}$ \\
\hline \multicolumn{3}{|c|}{ 300th anniversary park, Technosols } \\
\hline 1 & $0-20$ & 20.5 \\
\hline 2 & $0-20$ & 5.15 \\
\hline \multirow[t]{3}{*}{3} & $0-10$ & 25.3 \\
\hline & $10-20$ & 35.5 \\
\hline & $20-50$ & 11.0 \\
\hline 4 & $0-20$ & 50.5 \\
\hline 5 & $0-20$ & 27.8 \\
\hline 6 & $0-20$ & 13.6 \\
\hline 7 & $0-20$ & 16.3 \\
\hline 8 & $0-20$ & 37.8 \\
\hline 9 & $0-20$ & 12.2 \\
\hline \multicolumn{3}{|c|}{ South Seaside Park, Podzol } \\
\hline \multirow[t]{6}{*}{10} & $0-3$ & 21.4 \\
\hline & $3-12$ & 5.65 \\
\hline & $12-29$ & 9.25 \\
\hline & $29-51$ & 4.67 \\
\hline & $51-63$ & 5.00 \\
\hline & $63-91$ & 7.37 \\
\hline \multicolumn{3}{|c|}{ Undeveloped area near Leninsky Prospekt, Technosols } \\
\hline \multirow[t]{3}{*}{11} & $0-10$ & 7.79 \\
\hline & $10-20$ & 2.71 \\
\hline & $20-30$ & 3.94 \\
\hline \multirow[t]{3}{*}{12} & $0-10$ & 7.49 \\
\hline & $10-20$ & 0.41 \\
\hline & $20-30$ & 3.90 \\
\hline \multirow[t]{3}{*}{13} & $0-10$ & 0.36 \\
\hline & $10-20$ & 0.28 \\
\hline & $20-30$ & 0.18 \\
\hline
\end{tabular}

Microbial contamination of the soil directly and/or indirectly affects a people and living conditions. Sanitary and epidemiological requirements for soil quality in various territories are described in a number of official documents (MU 2.1.7.730-99, SanPiN 2.1.7.1287-03). They substantiated the regulations and standards for the permissible content of microorganisms.

Direct sanitary-bacteriological indicators of the epidemic danger of the soil are agents of intestinal diseases of humans 
Table 9

The degree of biological pollution of soils. Soil ID correspond to Table 3 .

\begin{tabular}{|c|c|c|c|c|c|c|}
\hline Soil ID & Depth, cm & $\begin{array}{l}\text { Index Coli bacteria } \\
\left(\text { colony } \cdot g^{-1}\right)\end{array}$ & $\begin{array}{l}\text { Pathogenic } \\
\text { flora }\end{array}$ & $\begin{array}{l}\text { Enterococcus } \\
\text { Index }\end{array}$ & $\begin{array}{l}\text { Helminth eggs } \\
\text { (instance } \cdot \mathrm{kg}^{-1} \text { ) }\end{array}$ & $\begin{array}{l}\text { Cysts of pathogenic } \\
\text { protozoa (in } 100 \mathrm{~g} \text { of soils) }\end{array}$ \\
\hline \multicolumn{7}{|c|}{ 300th anniversary park, Technosols } \\
\hline 1 & $0-20$ & 11 & - & 5 & - & - \\
\hline 2 & $0-20$ & 6 & - & 2 & - & - \\
\hline \multirow[t]{3}{*}{3} & $0-10$ & $<1$ & - & $<1$ & - & - \\
\hline & $10-20$ & - & - & - & - & - \\
\hline & $20-50$ & - & - & - & - & - \\
\hline 4 & $0-20$ & $<1$ & - & $<1$ & - & - \\
\hline 5 & $0-20$ & $<1$ & - & $<1$ & - & - \\
\hline 6 & $0-20$ & 2 & - & $<1$ & - & - \\
\hline 7 & $0-20$ & $<1$ & - & $<1$ & - & - \\
\hline 8 & $0-20$ & 4 & - & $<1$ & - & - \\
\hline 9 & $0-20$ & $<1$ & - & $<1$ & - & - \\
\hline
\end{tabular}

South Seaside Park, Podzol

\begin{tabular}{|c|c|c|c|c|c|c|}
\hline \multirow[t]{6}{*}{10} & $0-3$ & 5 & - & $<1$ & - & - \\
\hline & $3-12$ & - & - & - & - & - \\
\hline & $12-29$ & - & - & - & - & - \\
\hline & 29-51 & - & - & - & - & - \\
\hline & $51-63$ & - & - & - & - & - \\
\hline & $63-91$ & - & - & - & - & - \\
\hline \multicolumn{7}{|c|}{ Undeveloped area near Leninsky Prospekt, Technosols } \\
\hline \multirow[t]{3}{*}{11} & $0-10$ & 90 & - & 50 & - & - \\
\hline & $10-20$ & - & - & - & - & - \\
\hline & $20-30$ & - & - & - & - & - \\
\hline \multirow[t]{3}{*}{12} & $0-10$ & 70 & - & 35 & - & - \\
\hline & $10-20$ & - & - & - & - & - \\
\hline & $20-30$ & - & - & - & - & - \\
\hline \multirow[t]{3}{*}{13} & $0-10$ & 20 & - & 15 & - & - \\
\hline & $10-20$ & - & - & - & - & - \\
\hline & $20-30$ & - & - & - & - & - \\
\hline MPC & & Less 10 & Not available & Less 10 & Up to 10 instance $\mid \mathrm{kg}$ & Not available \\
\hline
\end{tabular}

“_“ not detected, MPC - maximum permissible concentration

and domestic animals - salmonella and other pathogenic enterobacteria. In our study, inoculation on pathogenic flora revealed a lack of growth, which corresponds to established standards (MU 2.1.7.730-99).

Indirect bacteriological indicators characterize the intensity of a foreign biological load on the soil. These are sanitary indicative microorganisms (SIMs) - common coliform bacte- ria or coli bacteria (CB), estimated by the coli index and fecal streptococci, evaluated by the enterococcus index. As a result of growing inoculation on differential breeding ground and identification, growth of both coliform bacteria and enterobacteria was detected. The $\mathrm{CB}$ index ranged from 1 to 90 . The enterococcus index was from 1 to 50 . In the studied parks, the values of these indices did not exceed or were at the border of 10, which 
allows them to be classified as "clean", according to current standards (Sokolov and Sokolov, 2014). A satisfactory degree of the epidemic hazard of the studied soils in the parks is apparently due to the fact that hygienic requirements for soil quality are established primarily for the most significant territories, which include recreation areas, including parks, for them are legally assigned rules for maintaining specially designated territories (SanPiN 2.1.7.1287-03). The data obtained of soils in the undeveloped territories of Leninsky Prospekt significantly differ from those obtained during research in the area of the parks of South Seaside and the 300th anniversary of St. Petersburg and correspond to the "moderately dangerous" class (SanPiN 2.1.7.1287-03). All excesses are concentrated in the horizon of 0-10 cm, where the CB indices are from 90 to 20 as they move away from residential buildings and the highway, and enterococcal indices from 50 to 15 with a similar decrease from the first to the third point of the study. In large cities and settlements with a high population density, the biological load on the soil is very high, and as a result, the SIMs indices are high. The increased number of SIMs indicate inappropriate walking of domestic animals, the use of recreational areas, etc. Account- ing for the number of coliform bacteria and enterococci allows you to indirectly control the degree of soil contamination with pathogenic bacteria, since (like SIM) the main sources of their entry into the soil (directly or with runoff) - these are sick people and animals, as well as carriers of pathogens (Sokolov and Sokolov, 2014).

Soil recovery from pathogens can occur as a result of exposure to adverse environmental conditions, the lack of the necessary nutrient substrate and, importantly, the antagonistic effect of the soil biota - bacteriophages, parasitic bacteria and protozoa. When some pathogens enter the rhizosphere of a number of plants, either their more rapid death occurs, or, on the contrary, their survival time increases (Sokolov and Sokolov, 2014).

\subsection{Statistical data processing}

Statistical processing on the content of chemical elements in the studied soils was carried out using the method of correlation analysis. Based on the correlation, one can hypothesize that the relation between all possible values of $\mathrm{X}$ and $\mathrm{Y}$ is linear. The statistical data are presented in Table 10.

\section{Table 10}

Correlation coefficients for the 300th anniversary park of St. Petersburg, South Seaside Park, Leninsky Prospekt.

For values of correlation coefficients depending on the mark with an asterisk significant at $p=0.05$

\begin{tabular}{|c|c|c|c|c|c|c|}
\hline $\mathrm{p}=0.05$ & $\mathrm{Cu}$ & $\mathrm{Pb}$ & $\mathrm{Cd}$ & As & $\mathrm{Ni}$ & $\mathrm{Zn}$ \\
\hline \multicolumn{7}{|c|}{ 300th anniversary park of St. Petersburg } \\
\hline $\mathrm{Cu}$ & 1.00 & 0.01 & 0.75 & 0.17 & -0.35 & -0.18 \\
\hline $\mathrm{Pb}$ & & 1.00 & -0.20 & 0.03 & 0.73 & -0.22 \\
\hline $\mathrm{Cd}$ & & & 1.00 & 0.12 & -0.26 & 0.09 \\
\hline As & & & & 1.00 & 0.17 & 0.17 \\
\hline $\mathrm{Ni}$ & & & & & 1.00 & 0.06 \\
\hline $\mathrm{Zn}$ & & & & & & 1.00 \\
\hline \multicolumn{7}{|c|}{ South Seaside Park } \\
\hline $\mathrm{Cu}$ & 1.00 & 0.80 & 0.41 & - & 0.84 & -0.24 \\
\hline $\mathrm{Pb}$ & & 1.00 & -0.16 & - & 0.93 & -0.20 \\
\hline $\mathrm{Cd}$ & & & 1.00 & - & 0.00 & 0.14 \\
\hline As & & & & 1.00 & - & - \\
\hline $\mathrm{Ni}$ & & & & & 1.00 & -0.33 \\
\hline $\mathrm{Zn}$ & & & & & & 1.00 \\
\hline \multicolumn{7}{|c|}{ Leninsky Prospekt } \\
\hline $\mathrm{Cu}$ & 1.00 & 0.36 & 0.04 & 0.08 & -0.19 & 0.26 \\
\hline $\mathrm{Pb}$ & & 1.00 & 0.25 & -0.28 & 0.41 & -0.23 \\
\hline $\mathrm{Cd}$ & & & 1.00 & -0.83 & -0.34 & -0.73 \\
\hline As & & & & 1.00 & 0.06 & 0.74 \\
\hline $\mathrm{Ni}$ & & & & & 1.00 & -0.08 \\
\hline $\mathrm{Zn}$ & & & & & & 1.00 \\
\hline
\end{tabular}


In the obtained data, an analysis was made of the matrix of correlation coefficients of the studied samples, which showed both positive and negative correlation between the concentrations of all elements. Due to the fact that there are no regularities in the distribution of chemical indicators along the profile of sections of alluvial soils, in contrast to natural soils (Kapelkina, 2010 b). A negative correlation indicates that with an increase in one component, another decreases.

A statistically significant correlation with confidence level $(P=0.05)$ was identified:

- in 300th anniversary park of St. Petersburg between: $\mathrm{Cu}$ and $\mathrm{Cd}(\mathrm{r}=0.75) ; \mathrm{Pb}$ and $\mathrm{Ni}(\mathrm{r}=0.73)$;

- $\quad$ in South Seaside Park between: $\mathrm{Cu}$ and $\mathrm{Ni}(\mathrm{r}=0.84)$; $\mathrm{Pb}$ and $\mathrm{Ni}(\mathrm{r}=0.93)$;
- in undeveloped area near Leninsky Prospekt between: $\mathrm{Cd}$ and As ( $\mathrm{r}=-0.83)$; $\mathrm{Cd}$ and $\mathrm{Zn}(\mathrm{r}=-0.73)$; As and $\mathrm{Zn}$ $(\mathrm{r}=0.74)$.

For all values having a high correlation $\left(0.7<\mathrm{r}_{\mathrm{xy}}<0.9\right)$ between the characters, according to the Cheddock scale (Hinkle et al., 2003), the significance of the correlation coefficient was calculated. As a result, all the obtained values were recognized as significant, except for $\mathrm{Cu}$ and $\mathrm{Pb}(\mathrm{r}=0.80)$ in the South Seaside Park. According to PCA analysis, lead and zinc accumulate mainly in the studied areas of the city (Fig. 3).

The source of lead in soils may be the proximity of highways and car exhausts. In general, zinc pollution in the soils of St. Petersburg is high, the average amount of zinc is higher than its normative value.

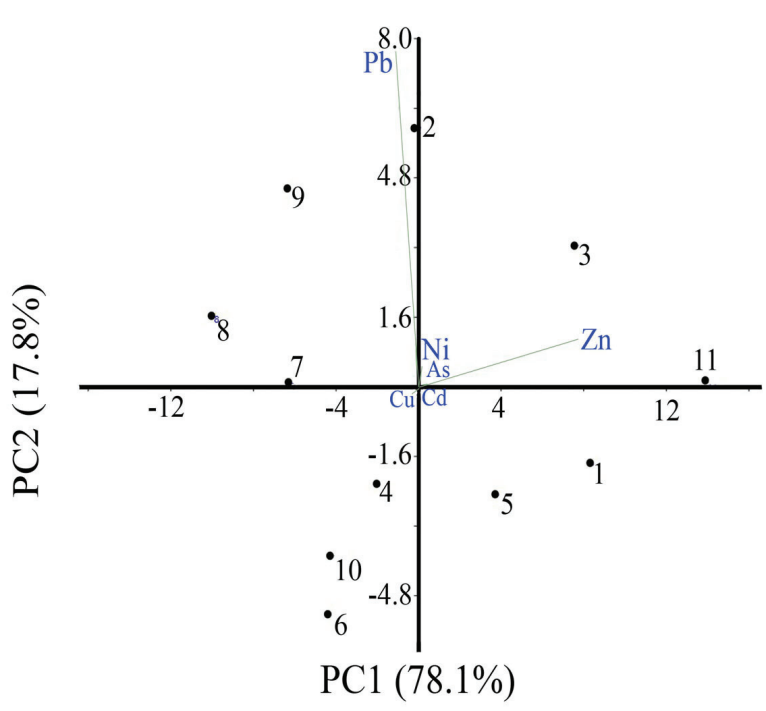

A

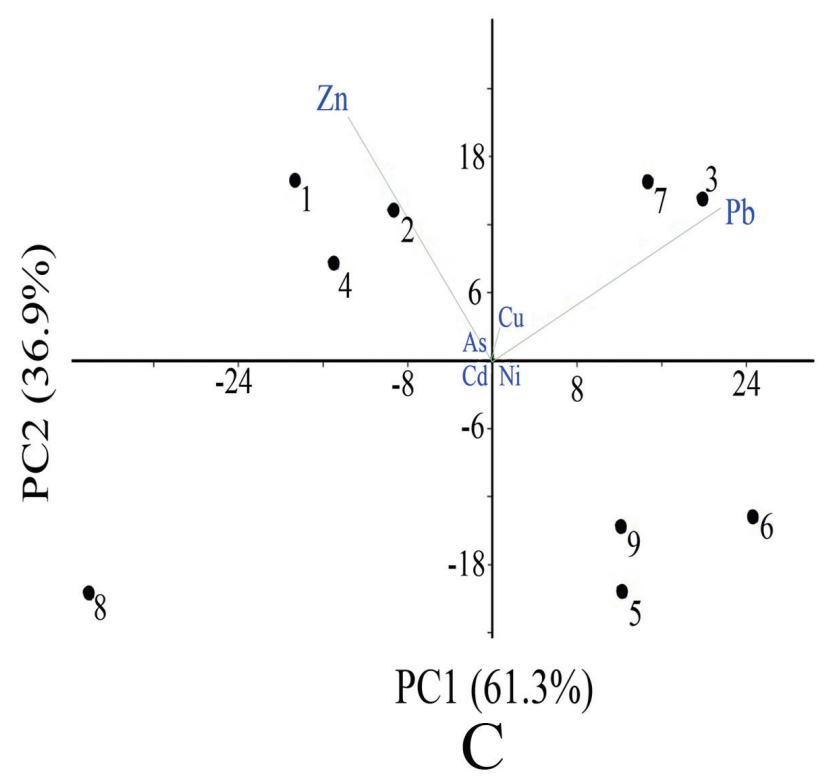

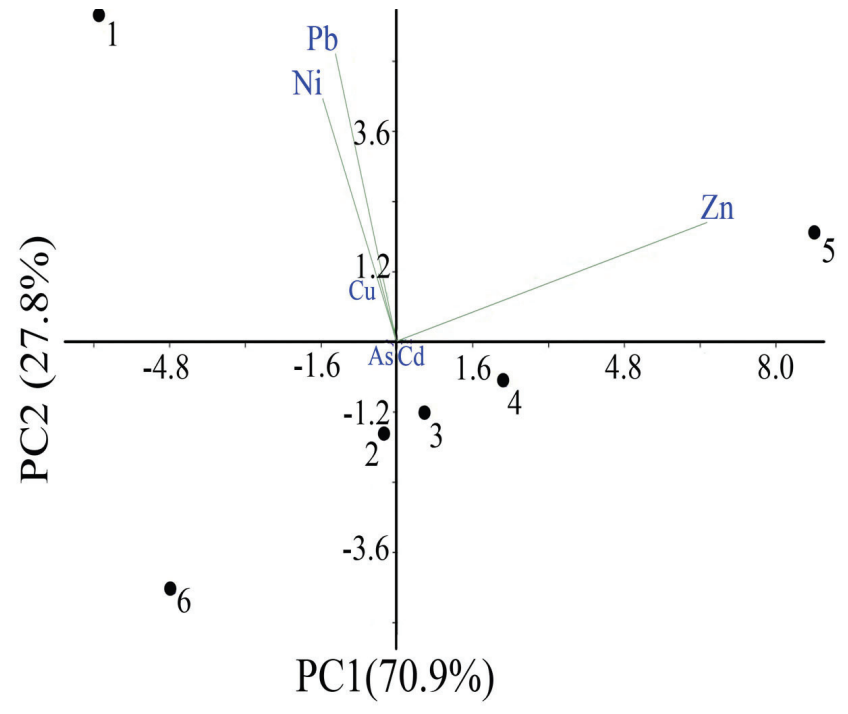

B

Fig. 3. PCA analysis of heavy metals in study soils. A - 300th anniversary park of St. Petersburg; B - South Seaside Park; C - Undeveloped area near Leninsky Prospekt 


\section{Conclusions}

To create an ecologically balanced system on alluvial soils, a set of measures is necessary. One of the practical tasks that these measures are aimed at is the reconstruction of the soil cover. Despite the ongoing preventive measures (sanitary cleaning, new plantings), on the territory of the parks can observe low excesses in HM and benzo[a]pyrene, however, the indicators of total pollution are not high. The territory of Leninsky Prospekt, where there is no organization of sanitary and hygienic control, is characterized by significantly higher concentrations of both pollutants and sanitary-indicative bacteria. We observe differences in the sanitary and hygienic conditions of alluvial territories specially designated for recreational area, where legislation is established and enforced to monitor compliance with hygiene requirements and undeveloped areas, where there are no various functioning systems that ensure an adequate sanitary level. Artificially created ecosystems are not able to exist for a long time without human impact.

\section{Acknowledgments}

This study was supported by grant "Urbanized ecosystems of the Russian Arctic: dynamics, state and sustainable development”

Publication of this article was co-financed by the Marshal's Office of Lubuskie Province in the framework of the competition Small Grants for Public Universities from Lubuskie Province.

\section{References}

Abakumov, E.V., Pavlova, T.A., Dinkelaker, N.V., Lemyakina, A.U., 2019. Sanitary assessment of the soil cover of the campus of Saint-Petersburg State University. Hygiene and Sanitation 1, 22-27. https://doi. org/10.18821/0016-9900-2019-98-1-22-27

Abdel-Shafy, H., Mansour M., 2016. A review on polycyclic aromatic hydrocarbons: Source, environmental impact, effect on human health and remediation. Egyptian Journal of Petroleum 25, 107-123. https:// doi.org/10.1016/j.ejpe.2015.03.011

Adama, M., Esena, R., Fosu-Mensah, B., 2016. Heavy metal contamination of soils around a hospital waste incinerator bottom ash dumps site. Journal of Environmental and Public Health 8926453. https://doi. org/10.1155/2016/8926453

Bi, X., Feng, X., Yang, Y., Qiu, G., Li, G., Li, F., Liu, T., Fu, Z., Jin, Z., 2006. Environmental contamination of heavy metals from zinc smelting areas in Hezhang County, Western Guizhou, China. Environment International 32, 883-890. https://doi.org/10.1016/j.envint.2006.05.010

Blume, H.P., 1989. Classification of soils in urban agglomerations. Catene 16, 269-275. https://doi.org/10.1016/0341-8162(89)90013-1

Bogdanov, N.A., 2014. Diagnostics of territories by integral indicators of chemical pollution of soils and soils. Hygiene and Sanitation 1, 92-97.

Cappuyns, V., Swennen, R., 2007. Classification of alluvial soils according to their potential environmental risk: A case study for Belgian catchments. Journal of Environmental Monitoring 9, 319-328. https://doi. org/10.1039/B616959G

Chasovskaya, V.V., 2007. Soil formation on alluvial soils in urban ecosystems. Abstract of thesis for the degree $173 \mathrm{pp}$. (In Russian).

Chen, T.B., Zheng, Y., Lei, M., Huang, Z., Wu, H. Chen, H., Fan, K., Yu, K., Wu, X., Tian, Q., 2005. Assessment of heavy metal pollution in surface soils of urban parks in Beijing, China. Chemosphere 60, 542-551. https://doi.org/10.1016/j.chemosphere.2004.12.072.
Dymov, A.A., Kaverin, D.A., Gabov, D.N., 2013. Properties of soil and soillike bodies, Vorkuta. Eurasian Soil Science 2, 240-248. https://doi. org/10.1134/S1064229313020038

Forstner, U., Ahlf, W., Calmano, W., Kersten, M., 1990. Sediment criteria development. Springer, Berlin.

Gabov, D.N., Beznosikov, V.A., Kondratenko, B.M., 2007. Polycyclic aromatic hydrocarbons in podzolic and peaty-podzolic-gley soils of background landscapes. Eurasian Soil Science 3, 282-291.

Gabov, D.N., Beznosikov, V.A., Kondratenko, B.M., Bushnev, D.A., 2004. Identification of polycyclic aromatic hydrocarbons in soils. Eurasian Soil Science 11, 1305-1312.

Ge, K.Y., 1992. The Status of Nutrient and Meal of Chinese in the 1990s. Beijing People's Hygiene Press, 415-434.

Hewelke, E., Szatyłowicz, J., Hewelke, P., Gnatowski, T., Aghalarov, R., 2018. The Impact of Diesel Oil Pollution on the Hydrophobicity and $\mathrm{CO}_{2}$ Efflux of Forest Soils. Water, Air, \& Soil Pollution 229, 51. https:// doi.org/10.1007/s11270-018-3720-6.

Hinkle, D.E., Wiersma, W., Jurs, S.G., 2003. Applied Statistics for the Behavioral Sciences. 5th ed. Boston: Houghton Mifflin, $756 \mathrm{pp}$.

Huot, H., Simonnot, M.O., Marion, P., Yvon, J., De Donato, Ph., Morel, J.-L., 2013. Characteristics and potential pedogenetic processes of a Technosol developing on iron industry deposists. Journal of Soils and Sediments 13, 555-568. https://doi.org/10.1007/s11368-012-0513-1

Inman, J.C., Parker, G.R., 1978. Decomposition and heavy metal dynamics of forest litter in northwest Indiana. Environmental Pollution 17, 34-51. https://doi.org/10.1016/0013-9327(78)90054-X

Iyengar, V., Nair, P., 2000. Global outlook on nutrition and the environment: meeting the challenges of the next millennium. Science of the Total Environment 249, 331-346. https://doi.org/10.1016/s00489697(99)00529-x

Ji, X., Abakumov, E., Polyakov, V., 2019. Assessments of pollution status and human health risk of heavy metals in permafrost-affected soils and lichens: A case-study in Yamal Peninsula, Russia Arctic. Human and Ecological Risk Assessment: An International Journal 25(8), 2142-2159. https://doi.org/10.1080/10807039.2018.1490887.

Kapelkina, L.P., 1994. Ecological bases of the recultivation of man-made and urbanized landscapes in the forest zone. Abstract of thesis for the degree 40 pp. (In Russian)

Kapelkina, L.P., 2010a. Some environmental aspects of land reclamation. Regional Ecology 4(30), 40-43. (in Russian).

Kapelkina, L.P., 2010b. Pollutants in soils of megacities. Problems and paradoxes of rationing. Ecology of urban areas 3, 13 pp. (In Russian)

Kicińska, A., 2019. Environmental risk related to presence and mobility of As, $\mathrm{Cd}$ and $\mathrm{Tl}$ in soils in the vicinity of a metallurgical plant - Longterm observations. Chemosphere 236, art. No. 124308, https://doi.org/ doi.org/10.1016/j.chemosphere.2019.07.039

Kicińska, A.J., Smreczak, B., Jadczyszyn J., 2019. Soil Bioavailability of Cadmium, Lead, and Zinc in the Areas of $\mathrm{Zn}-\mathrm{Pb}$ Ore Mining and Processing (Bukowno, Olkusz). Journal of Ecological Engineering 20(1), 84-92, https://doi.org/10.12911/22998993/93794.

Li, X., Scott, C., Salifu, F., 2014. Soil texture and layering effects on water and salt dynamics in the presence of a water table: A review. Environmental Reviews 22(1), 41-50. https://doi.org/10.1139/er-2013-0035

Lodygin, E.D., Chukov, S.N., Beznosikov, V.A., Gabov, D.N., 2008. Polycyclic aromatic hydrocarbons in the soils of Vasilyevsky Island (St. Petersburg). Eurasian Soil Science 12, 1494-1500.

Maximova, E., Abakumov, E., 2015. Alluviated soils of the Saint-Petersburg City. Biological Communications 4, 93-102. https://doi.org/10.21638/ spbu03.2015.408

Mikhailova, A.A., Popova, L.F., Nakvasina, E.N., 2016. Ecological and biological features of oil pollution of soils in Arkhangelsk. Northern (Arctic) Federal University 150 pp. (In Russian).

Ministry of the Environment and Natural Resources of the Russian Federation, 1993. About the procedure for determining the extent of damage from chemical pollution of land.

MR FTs/4022-04 Methods of microbiological soil control guidelines. 
MU 2.1.7.730-99. Hygienic assessment of soil quality in populated areas. (In Russian)

MU 31-18/06. Methodology for measuring mass concentrations of nickel and cobalt in soils, greenhouse soils, sapropels, silts, bottom sediments and solid waste by inversion voltammetry on TA analyzers. $40 \mathrm{pp}$.

Muller, G., 1998. Chemical decontamination of dredged materials, combustion residues, soil and other materials contaminated with heavy metals. In: Proceedings of the 2nd internetional TNO/BMFT conference on contaminated soils 2, $1 \mathrm{pp}$.

Nikiforova, E.M., Kosheleva, N.E., 2011. Polycyclic aromatic hydrocarbons in urban soils (Moscow, Eastern District). Eurasian Soil Science 9, 1114-1127.

PND F 16.1.21-98. Methodology for measuring the mass fraction of oil products in soil and soil samples by a fluorimetric method using the FluorAT-02 liquid analyzer. $22 \mathrm{pp}$.

PND F 16.1:2:2.2:3.39-03. Quantitative chemical analysis of soils. Methodology for measuring the mass fraction of benz(a)pyrene in samples of soils, soils, solid waste, bottom sediments by high performance liquid chromatography using a Lumahrom liquid chromatograph. 2 pp.

SanPiN 2.1.7.1287-03. Sanitary and epidemiological requirements for soil quality (In Russian).

SanPiN 4266-87. Methodological guidelines for assessing the degree of danger of soil contamination with chemicals, $10 \mathrm{pp}$. (In Russian).

Scharenbroch, B.C., Lloyd, V.E., Johnson Maynard, J.L., 2005. Distinguishing urban soils with physical, chemical, and biological properties. Pedobiologia 49, 283-296. https://doi.org/10.1016/j.pedobi.2004.12.002

Sezgin, N., Ozcan, H.K., Demir, G., Nemlioglu, S., Bayat, C., 2003. Determination of heavy metal concentrations in street dusts in Istanbul E-5 highway. Environment International 29, 979-985. https://doi. org/10.1016/S0160-4120(03)00075-8

Shakhverdov, V.A., Shakhverdova, M.V., 2015. Types and pollution factors of the eastern Gulf of Finland and its coastal zone. News of Russian State Ped. University 176, 101-113. (In Russian).

Shamilishvily, G., Abakumov, E., Gabov, D., 2018. Polycyclic aromatic hydrocarbon in urban soils of an Eastern European megalopolis: Distribution, source identification and cancer risk evaluation. Solid Earth 9(3), 1-19. https://doi.org/10.5194/se-9-669-2018

Shikhova, N.S., 2005. Monitoring the physical condition of urban soils in connection with landscaping problems. Siberian Ecological Journal 5, 899-907 (In Russian).
Short, J.R., Fanning, D.S., McIntosh, M.S., Foss, J.E., Paterson, J.C., 1986. Soils of the mall in Washington, D. C. Soil Science Society of America Journal 50, 699-705. https://doi.org/10.2136/sssaj1986.0361599500500 0030030x

Sodango, T.H., Li, X., Sha, J., Bao, Z., 2018. Review of the Spatial Distribution, Source and Extent of Heavy Metal Pollution of Soil in China: Impacts and Mitigation Approaches. Journal of Health and Pollution 8(17), 53-70. https://doi.org/10.5696/2156-9614-8.17.53

Sokolov, M.S., Sokolov, D.M., 2014. Sanitary-bacteriological evaluation of soils and organic fertilizers. Eurasian Soil Science 5, 3-19.

Sorokin, N.D., Koroleva, E.B., Loseva, E.V., Osintseva, N.V., 2012. Manual on the study of polluted lands and their rehabilitation, ENPI $119 \mathrm{pp}$. (In Russian).

Sposito, G., 1989. The chemistry of soils. USA: Oxford University Press, $277 \mathrm{pp}$.

Suman, J., Uhlik, O., Viktorova, J., Macek, T., 2018. Phytoextraction of Heavy Metals: A Promising Tool for Clean-Up of Polluted Environment? Frontiers in Plant Science 16. https://doi.org/10.3389/ fpls.2018.01476.

Syed, J.H., Iqbal, M., Zhong, G., et al., 2017. Polycyclic aromatic hydrocarbons (PAHs) in Chinese forest soils: profile composition, spatial variations and source apportionment. Scientific Reports 7(1), 2692. https://doi.org/10.1038/s41598-017-02999-0

Ufimtseva, M.D., Terekhina, N.V., Abakumov, E.V., 2011. Physico-chemical characteristics of urban soils of the Central district of St. Petersburg. Bulletin of St. Petersburg University 4, 85-97.

Vodyanitsky, Y.N., Yakovlev, A.S., 2011. Assessment of soil contamination by the content of heavy metals in the soil profile. Eurasian Soil Science 44(3), 297-303.

Wei, B., Yang, L., 2010. A review of heavy metal contaminations in urban soils, urban road dusts and agricultural soils from China. Microchemical Journal 94, 99-107. https://doi.org/10.1016/ j.microc.2009.09.014

WRB, (2015). World reference base (WRB) for soil resources, international soil classification system for naming soils and creating legends for soil maps. Rome; Food and Agriculture Organization of the United Nation (FAO).

Zelinkova, Z., Wenzl, T., 2015. The Occurrence of 16 EPA PAHs in Food -A Review. Polycyclic Aromatic Compounds 35(2-4), 248-284. https:// doi.org/10.1080/10406638.2014.918550

\section{Stan ekotoksykologiczny i stopień zanieczyszczenia gleb aluwialnych Petersburga, Rosja}

\section{Słowa kluczowe \\ Zanieczyszczenia gleb \\ Gleby miejskie \\ Gleby technogeniczne \\ Tereny przekształcone \\ Gleby bielicowe}

\section{Streszczenie}

Właściwości gleb na terenach miejskich znacznie różnią się od gleb występujących na obszarach niezurbanizowanych. Obszary zurbanizowane są narażone na negatywne oddziaływania o charakterze głownie antropogenicznym, wpływające na funkcje ekologiczne gleb. Z powodu ich nasilenia daje się zaobserwować wzrost zanieczyszczenie powietrza powierzchniowego, zaburzeń w obrębie profilu glebowego; zmienia się kwasowość i zasadowość gleb, a różnorodność biologiczna mikroflory glebowej maleje. Celem pracy była ocena stanu sanitarno-chemicznego i sanitarno-mikrobiologicznego terenów aluwialnych położonych w parkach 300 lecia Petersburga i w parku Południowo-Nadmorskim, a także obszaru położonego w pobliżu Alei Lenina. W pracy przedstawiono wyniki badań przeprowadzonych na aluwialnych glebach miejskich parków i strefy przemysłowej w Petersburgu. Wszystkie analizowane gleby zostały scharakteryzowane jako technosole. Określono morfologię i podstawowe parametry fizyczne gleb. Określono zawartość priorytetowych substancji toksycznych (metale ciężkie, benzo-a-piren, produkty ropopochodne), a także przeprowadzono badania epidemiologiczne gleb pod kątem obecności organizmów chorobotwórczych. Uzyskane wyniki pozwoliły na wykorzystanie wskaźnika zanieczyszczenia chemicznego (Zc) oraz wskaźnika geoakumulacji (Igeo) do oceny stopnia zanieczyszczenia gleby. Uzyskane wyniki jednoznacznie pokazują, że metale ciężkie gromadzą się w wierzchnich poziomach gleb aluwialnych (przy czym w około 35\% badanych gleb stwierdzono przekroczenie dopuszczalne stężenia). Podobną zależność odnotowano w przypadku WWA. Obecność organizmów chorobotwórczych była zróżnicowana, jednak zmieniała się w dopuszczalnych granicach obowiązujących w Rosji. 